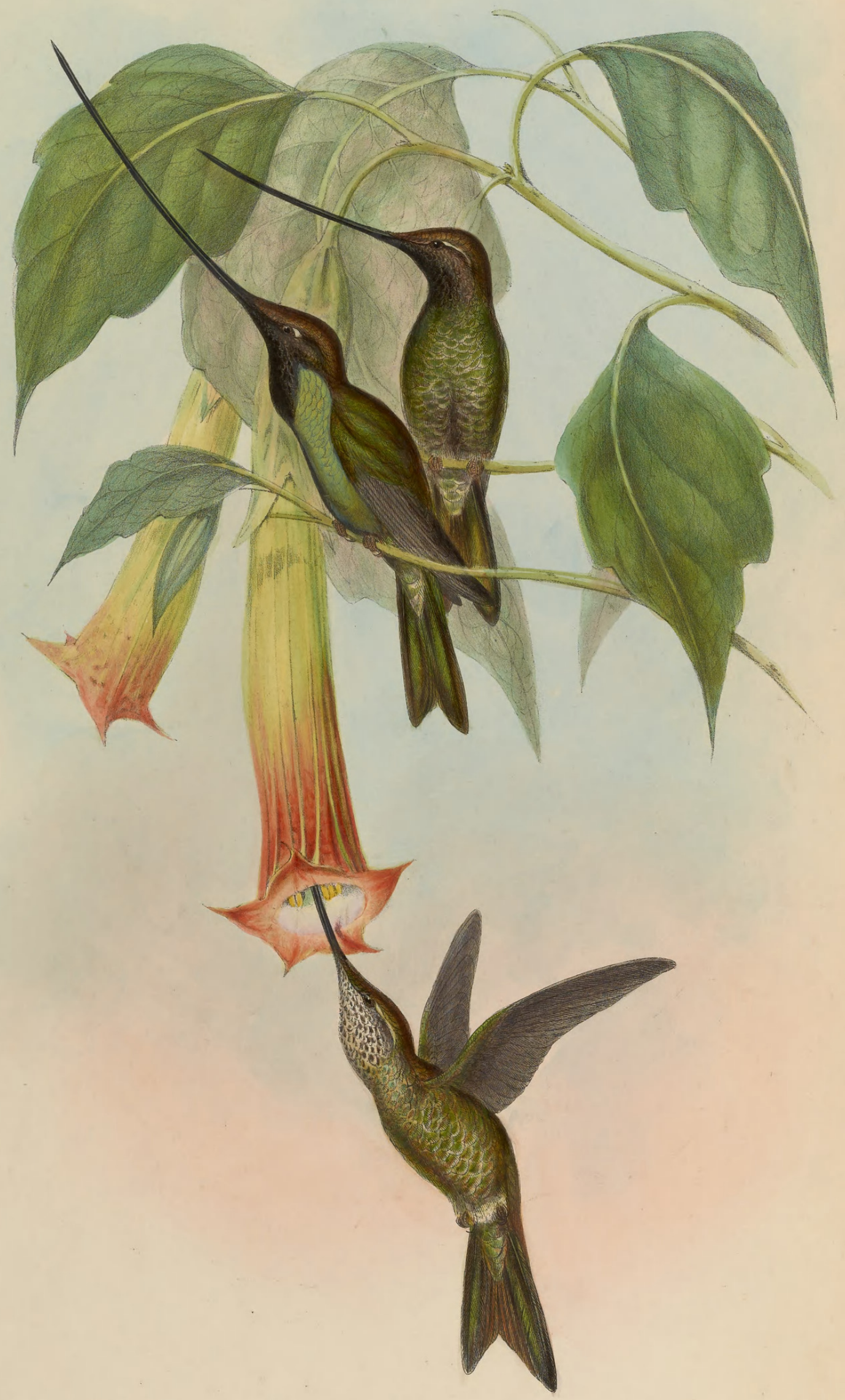




\section{DOCIMASTES ENSIFERUS.}

Sword-bill.

Ornismya ensifera, Boiss. Rev. Zool. 1839, p. 354.-Mag. de Zool. 1840, Ois. pl. 15.-Lodd. in Proc. of Zool. Soc., Part XI. 1843, p. 122.

Trochilus Derbianus, Fras. in Proc. of Zool. Soc., Part VIII. 1840, p. 16.

Mellisuga ensifera, Gray and Mitch. Gen. of Birds, Mellisuga, sp. 1.

THIS is another of the new and very remarkable species that have rewarded the researches of modern naturalists in the magnificent region of Santa Fé de Bogota, where most of the specimens sent to Europe have been procured; it appears, however, to possess a wide range, for I have heard of its being observed in the Caraccas, and my friend Sir Willian Jardine, Bart., has lately received from Mr. Jameson an example obtained in the shrubby region on Pichincha in Quito, at an elevation of from 11,000 to 12,000 feet above the sea.

Mr. Hartweg, the celebrated botanical traveller, informs me that he has seen this bird in a state of nature, and that he frequently saw it engaged in procuring its insect food from the lengthened corollas of the Brugmansice, for exploring which its lengthened bill is so admirably fitted ; affording another instance of the wonderful adaptation of structure to a given purpose so frequently observable in every department of Nature's works.

The male has all the upper surface and the wing-coverts bronzy green, assuming a coppery hue on the head; behind the eye a spot of white; throat blackish brown ; on either side of the throat a broad crescentic band of shining emerald green; under surface bronzy green ; under tail-coverts bronzy green, fading into white on the edges of the feathers; wings purplish brown; tail dark brown with a bronzy lustre; bill blackish brown ; feet yellowish brown.

Total length, $8 \frac{3}{4}$ inches; bill, 4 ; wing, 3 ; tail, $2 \frac{1}{4}$; tarsus, $\frac{1}{4}$.

The female has the upper surface as in the male, except that a few white feathers appear on the lower part of the back; a line of white is also perceptible behind the eye; wings purplish brown; tail olivegreen ; throat brown, each feather margined with gray; under surface bronzy green, mottled with brown, and an indication of the bright bands on either side of the throat.

Total length, $6 \frac{1}{2}$ inches; bill, 3 ; wing, 3 ; tail, $2 \frac{1}{4}$; tarsus, $\frac{1}{4}$.

The upper surface of the young male is of a more coppery hue than that of the adult; the throat is mottled brown and white, produced by each feather having an oblong spot of brown at the tip; on either side of the throat a band of lustrous green with bronzy reflexions, amidst which the white bases of the feathers here and there appear; under surface coppery green, interrupted in like manner by the white bases of the feathers; under tail-coverts green, slightly margined with white.

Much variation is found in the length of the bill in different individuals; I have remarked too that the young males of the year have longer bills than the adults; one of the former in my own collection measures four inches and three-eighths from the gape to the tip.

The figures represent an adult male and female, and a young male, all of the natural size, on the Scarlet Trumpet Flower (Brugmansia sangruinea). 


\section{$2 \mathrm{BHL}$ Biodiversity Heritage Library}

Gould, John. 1858. "Docimastes ensiferus, Sword-bill. [PI. 233]." A monograph of the Trochilidae, or family of humming-birds 4, https://doi.org/10.5962/p.317042.

View This Item Online: https://www.biodiversitylibrary.org/item/108334

DOI: https://doi.org/10.5962/p.317042

Permalink: https://www.biodiversitylibrary.org/partpdf/317042

\section{Holding Institution}

Smithsonian Libraries

\section{Sponsored by}

Smithsonian Institution Libraries

\section{Copyright \& Reuse}

Copyright Status: NOT_IN_COPYRIGHT

This document was created from content at the Biodiversity Heritage Library, the world's largest open access digital library for biodiversity literature and archives. Visit BHL at https://www.biodiversitylibrary.org. 